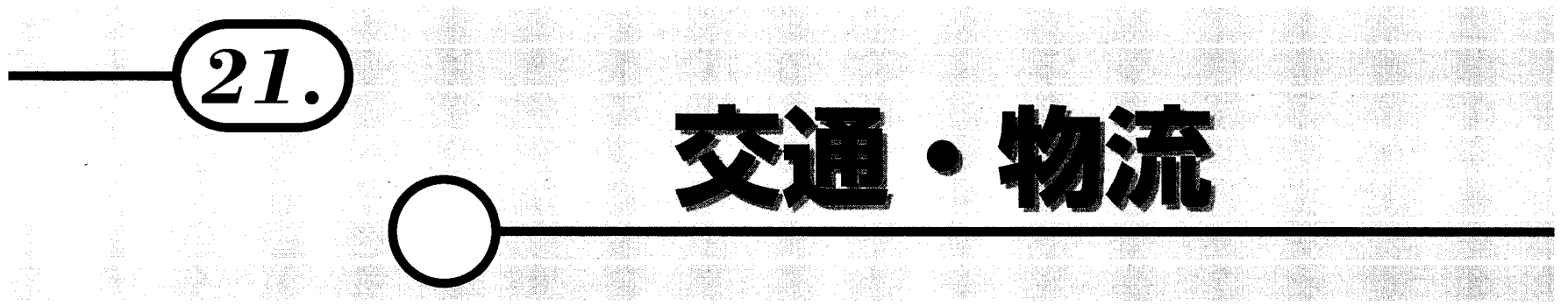

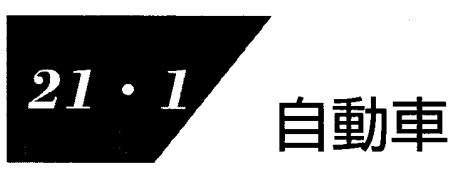

\subsection{1 概況}

a. 生産 2012 年の四輪車生産は 994 万台（前年比 $18.3 \%$ 増）で，内訳は乗用車 855 万台，トラック 127 万台，バス 12 万台で，二輪車生産は 60 万台 (同 $6.3 \%$ 減) である.

b. 輸出 2012 年の新車輸出は乗用車 420 万台 (同 $6.9 \%$ 増) で生産に占める割合は $49.1 \%$ で 2011 年より $10.5 \%$ 減少した.

二輪車は 48 万台（同 $4.0 \%$ 減）で生産に占める割合は $80 \%$ で 2011 年より $2.4 \%$ 増加した.

c. 輸入 2012 年の日本メーカ車を含めた輸入車新規登録 台数は 31.6 万台で，前年比 $14.9 \%$ 増となった.

d. 保有台数 2012 年 12 月末で, 乗用車 5787 万台, トラッ ク 1590 万台, バス 23 万台, 原付を除く二輪車 355 万台になつ ている.

[関根 康史 三菱自動車工業 (株)]

\section{1:1・2 四輪自動車の技術動向}

低燃費化に向けた多様な技術が市場に導入された。パワート レーン技術では，クリーンディーゼルエンジン・直噴ミラーサ イクル十スーパチャージャのダウンサイジングエンジン, 減速 エネルギー回生技術については，専用のリチウムイオンバッテ リー・電気二重層キャパシタの採用・スタータ機能付きオルタ ネータを補助原動機として HEV (Hybrid Electric Vehicle) 化 した車雨などである．また，アイドリングストップシステムに ついては，蓄冷技術によるエアコン停止への対応・エンジン停 止車速の引き上げなど，実走行におけるエネルギー効率を高め る技術の普及である，車体の軽量化では，テーラードブランク 材・軽量樹脂材料・スチールとアルミの接合技術といった高剛 性化と軽量化の両立技術開発がなされた.

安全技術では，衝突回避支援警報およびブレーキ・誤発進お よび急発進抑制機能・アダプティブクルーズコントロール・車 線逸脱警報などをパッケージ化したシステムが市場導入され た. 前方監視デバイスについては, ミリ波レーダ・カメラ・レー ザなど多様化と低コスト化が進み, 軽自動車にも採用されて予 防安全システムの普及が進められた．また，先行車および対向 車を検知して自動的に遮光するハイビームや後側方車両検知な ど，視界支援システムの進化も見られた.

また，プラグイン HEV が市場導入され，EV (Electric Vehicle）とともに社会全体で環境負荷を抑える取り組みとし てのスマートグリッドの実証実験が自治体中心に各地で進めら れた. 未来都市構想の重要アイテムとして超小型モビリティが 注目される中で，その定義と車両仕様に対する要求などの議論 が進められた。

[門崎 司朗 トヨタ自動車 (株)]

\subsection{3 二輪車の技術動向}

国内外で交通事故死傷者数削減に向けた安全技術研究への関 心がいっそう高まった. ヨーロッパでは，標準化の動きに対応
した ABS（Antilock Brake System）搭載機種が増加し，姿勢 センサを利用した車両姿勢制御機能の搭載が進んでいる.一方, 国内では着用タイプのエアバックが普及しつつある.

環境に関わるところでは，新興国での FI（Fuel Injection） 化や低フリクション化など小型エンジンでの燃費向上の取り組 みが加速した。中国では電動自転車が急激に増加しており， 3000 万台規模の市場に成長した。

〔藤井茂 ヤマ八発動機（株）〕

\section{I - J - 1 生産技術・材料}

近年, 地球環境保全や衝突安全性向上のニーズがますます高 くなり，自動車には，さらなる軽量化と高剛性・高強度の相反 する性能の両立が求められている.

車体技術では，車体部品への高張力鋼板の採用が進められ， 衝突安全に関わる構造骨格部品においては，980MPa 級の高張 力鋼板の採用が増加している.さらなる高強度化技術としては, $1500 \mathrm{MPa}$ 級のホットプレス工法の適用も進んでいる.

エンジン技術では，材料の鉄からアルミへの置換が進んでお り, 高強度が要求されるディーゼルエンジンのシリンダブロッ

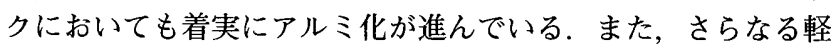
量化と高機能化に対応するために，より薄肉・複雑形状の製品 も求められている.

一方，生産ラインでは，既存のガソリン車とハイブリッド車 や電気自動車との泚流生産など，よりフレキシブルな生産体制 が求められている.

\section{$21 \cdot 1 \cdot 5$ 基礎研究}

a. 運動性能駆動力配分と予測制御などを用いて，運動 性能に留まらず快適性と省エネルギーなど，トータルでのクル マ性能を目指した研究が数多くなされた.

b. 安全 走行環境情報を基に，危険を予測して近づかな い手法の提案と隊列走行の可能性を探る研究が加速された。

c. 環境実用燃費向上を目的に, 補機, 空力, 軽量化など, 車 1 台分での評価を行う研究がなされた。

〔河合 俊岳 (株) 本田技術研究所〕

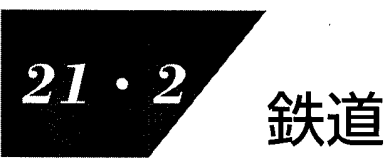

\section{$21 \cdot 2 \cdot 1$ 概況}

わが国における 2012 年 1 月〜 12 月の鉄道車両生産 (新造) は 1683 両で，2011 年をさらに下回り低下傾向が続いた。内 訳は, 国内向け 1582 両 (うち新幹線 280 両), 輸出は 101 両 であった. (国土交通省鉄道車両等生産動態統計月報より)

2011 年の東日本大震災で被災した路線の復旧が図られたが, まだ運休区間が残っている $(2013$ 年 4 月時点で $271 \mathrm{~km})$. また, 9 月の九州北部豪雨のような自然災害に対する復旧活動もなさ れ，さらなる防災・減災対策が推進されている．なお，2012 年の鉄道新線開業はなかった.

鉄道の国際標準化関係では，交通安全環境研究所の鉄道認証 